\title{
Dreaming faith into being: Indigenous Evangelicals and co-acted experiences of the divine ${ }^{1}$
}

\author{
MINNA OPAS \\ University of Turku
}

\begin{abstract}
This article examines the role of socio-moral space in people's experiences of divine presence. More specifically, it addresses the questions of how social others influence people's experiences of God and Satan among the indigenous evangelical Yine people of Peruvian Amazonia, and the consequences these interactions have for the individual believer and the collectivity. For the Yine dreams are a privileged site of human encounter with other-than-human beings, and they also feature centrally in their Christian lives. It is in dreams that they interact with angels and sometimes with the devil. By examining Yine evangelical dreams as mimetic points of encounter involving not only the dreamer but also transcendent beings and fellow believers as active agents, the article shows that Yine experiences of God's presence cannot be conceptualised as an individual matter, but are highly dependent on the social other: they come to be as co-acted experiences of the divine.
\end{abstract}

Keywords: Christianity, evangelicals, dreams, mimesis, co-acted experiences, Yine, Peru

'When we Yine have bad dreams, when we have nightmares, it is because of the devil.' (An evangelical Yine woman in her sixties.)

'You have to tell others about your dreams, otherwise the bad things in the dreams will come to pass.' (An evangelical Yine woman in her fifties.)

Ethnographic and textual descriptions of how Christians - Pentecostals and Charismatics, in particular - depict the moment when they experience the presence of God, Jesus, or the Holy Spirit, and how they thereafter perceive this connection, demonstrate that relatedness with the divine often becomes tangible through bodily sensations such as warmth, shivering, and a feeling of good, or their lack. Through such experiences people become aware of

1 This research has been funded by the Academy of Finland and the Turku Institute for Advanced Studies. 
their connection with God, their oneness with God, or perhaps their separation from God. Christians and scholars alike - theologians as well as humanists and social scientists - have attempted to understand and verbalise such sensations or, in Birgit Meyer's (2010, 742) words the 'experiential presence', in various ways. The fundamental problem in the endeavour is linked to the 'problem of presence' (Engelke 2007), that is, the problem of making the transcendent present in this world: how can people perceive what by definition cannot be perceived (Gavrilyuk \& Coakley 2011; Hart \& Wall 2005)? Scholarly accounts concerned with the mechanisms through which Christians feel being connected with the divine have customarily taken their cue from this problem, and have distinguished between the tangible and intangible or physical and non-physical in one way or another (e.g. Gavrilyuk \& Coakley 2011; Harding 2000). However, the material turn of recent decades has encouraged research to go beyond the physical-non-physical division in the study of these experiences, which have become understood as something much more material than spiritual (in an immaterial sense). The languages of embodiment (Csordas 1994; Klaver \& van de Kamp 2011), tactility (Chidester 2005), and metakinesis (Luhrmann 2004), for example, have been used to describe the physicality of the Christian experiences of divine presence. ${ }^{2}$ Although such material approaches have contributed importantly to our understanding of the human-divine relationship, they have done so at the expense of sociality. Many approaches to the human-divine relationship focus on the relationship the individual believer has with the Christian divine, and take no account of the role of fellow believers and other people in the generation of such experiences. In doing so, they continue the long tendency of viewing Christian subjects as individuals (see Bialecki \& Daswani 2015; Daswani 2011; Keane 2007; Mosko 2010; Robbins 2002; Vilaça 2011). Although the role of social others may be acknowledged, it is rarely the examination's focus. Despite recent efforts to bring social relationships into the analysis of these experiences (e.g. Bialecki 2014; Coleman 2006; de Witte 2009; Luhrmann 2012; Mitchell 2015), the topic remains understudied.

This article recognises this gap in research and aims, by examining people's connections with God among the indigenous Amazonian evangelical Yine people, to contribute to the study of the social other as part of Christian experiences of divine. The Yine are an indigenous group living

2 For other studies on the experiences of the presence of the Christian divine, see e.g. AustinBroos 1997; Brahinsky 2012; Cattoi \& McDaniel 2011; Coleman 2006; de Witte 2009; Griffith 2004; McGuire 2003. For similar experiences in other contexts, see e.g. Espirito Santo \& Tassi 2013. 
in the Peruvian lowlands. While many Yine already live or study in cities, the majority still live in small communities in the lowland rainforest area. Most Yine are Christian, mainly Catholics, Evangelicals, and Pentecostals, but there are also some who are non-religious. The first Yine contacts with Christianity took place with the arrival of Catholic missionaries as early as the 17th century, but in south-eastern Peruvian Amazonia, for example, the Yine were evangelised only from the 1950s, first by the Summer Institute of Linguistics/Wycliffe Bible Translators, and latterly by the missionaries trained at the Swiss Mission near Pucallpa, Peru. This article is based on ethnographic fieldwork conducted with the Yine people in the Urubamba and Madre de Dios regions in lowland Peruvian Amazonia between 2012 and 2015.

Yine evangelical experiences of the divine presence were inseparably material and social. They were material in that they took place as physical sensations. Yine evangelicals described the condition of being connected to the divine as a lightness of and warmth in the body, or as feelings of denseness within the body. However, these experiences were not mere sensations to them. Some, albeit not all, Yine Evangelicals understood faith and divine presence as materialising as a special organ called ruwekinri (his/ her life) within a person's body. This organ was invisible, yet perceptible by other senses - it was the site of the experiences of lightness, warmth, and denseness, and from which they emanated. It was affected by the Holy Spirit, which made it grow and thus more easily felt physically. As such, it was also considered to be an important index of a person's faith (Opas, forthcoming). The experiences of the divine that took place through or as this special faith organ were not, however, a question merely of individuals' relationship with the divine, the Holy Spirit, or God. They came to be as what I will term 'co-acted experiences of the divine'. I use this term to refer to people's experiences of divine presence that arise from a social process involving not only the believer and the divinity but also fellow believers and other kindred people (and, in some cases, also other-than-human beings). The social others were an elemental part of the Yine evangelical processes of formation and interpretation of a person's physical sensations of the divine. This was so not only in the general sense of culture affecting the individual's possibilities for interpretation, but also in practice as the evangelicals struggled to live well as Christians. It was in relation to other people that a person's Christian condition was evaluated, and thus linked to the dynamics of everyday social life. This was not a social understood separately from materiality but one that was dependent on the practices of consubstantialisation aimed at life among consubstantial people. 
A central locus for the co-acting of experiences of God's presence was dreams, which for the Yine evangelicals were an important 'sensational form' (Meyer 2010) through which the divine became tangible. Instead of a product of an individual person's imagination, for the Yine dreams were sites of social encounter (both with transcendent and immanent others) where the past, present, and future were conjoined. As such, they were an integral part of people's daily life. In this article I will approach evangelical Yine people's dreams as a nexus of social relationships that produces experiences of God's presence and people's faith that materialise as the faith organ, ruwekinri. The main focus is on the role of social others in these processes: what are the dream-related ways in which social others (human and divine) take part in the production of experiences of God's presence, and what effect does their involvement have on the individual's faith and on the community of believers? This discussion relates to a wider scholarly project which attempts to surpass the modern purified and intellectualist approaches to religion and belief, and to anchor them instead to people's everyday material and socio-moral practices (Bialecki 2014; Keane 2007; McGuire 2003; Meyer 2008; Orsi 2006).

I will first examine Yine evangelicals' views of the nature of ruwekinri as a material faith organ, and then study Yine dreaming and dream-sharing in general, and as part of their Christian praxis in particular. Then, to capture the multiplicity involved in these interactions, I will develop the idea of coacted experiences of the divine, and argue that these co-acted experiences are best understood as processes of affective mimesis. Finally, I will briefly depart from the study of human social others to discuss the role of Christian divinities as co-actors in the generation of faith among Yine evangelicals.

\section{Yine experiences of the divine}

One evangelical Yine woman in her fifties explained the physical nature of the human relationship with the Holy Spirit to me as follows:

We cannot understand [Giwekikaluru] Kpashiri (Holy Spirit). Although we hear the Word of the Lord, we cannot believe, we cannot calibrate, we cannot understand, because it is kpashiri (respect). But the words of this world we do understand quickly.... One has to receive the Word of God, then it stays in the heart, kpashiri stays in your body.

In this woman's account the presence of the Holy Spirit is something that cannot be comprehended, but must be materialised in the body for a person 
to connect with it. It must be physically experienced. In one Yine evangelical account, the effects of the Holy Spirit were compared with the nutrition of the foetus in a mother's womb. Just as the foetus is nourished by the mother and so little by little begins to live and gain strength, so God gives people life and nourishes them with the Holy Spirit (see Opas forthcoming). When incorporated into the body, the presence of the Holy Spirit may be felt as its confidence, strength, and fearlessness.

This view is emblematic of the physiology of Yine epistemology. The Yine consider that thinking and thoughts are generated in the heart and from there are raised in the head or mind. Although everyday 'words of this world' are easily understood, most Yine with whom I discussed this mentioned the role of the heart in the process of understanding and thinking. The heart was considered an affective core of the emotions and thinking. What is noteworthy is, as noted above, that the sensation of being nourished by the Holy Spirit was neither a mere feeling of having the strength to work nor merely a sensation, but was thought by some evangelicals to constitute a special 'organ', ruwekinri, his/her life, located in the person's chest or heart. It was this organ, which gained strength and grew when nourished by God, the Holy Spirit, and faith. Although not all Yine evangelicals accepted the idea that ruwekinri formed a separate organ - some considered it to be one with the heart or located in it - it was still understood to be something profoundly material and affected by God.

However, ruwekinri was not merely the materialisation of an individual's faith and relationship with God but was also more widely involved in the organisation of the evangelical community of believers among the Yine. Its existence was one way to evaluate the Christian condition of a person, which in a relational society also affected others' conditions. Yine social production and organisation relied on the property of consubstantialisation, which meant that people influenced one another's bodies, and thus personhood, through the sharing of different corporeal and other substances and through physical proximity. This form of sociality made personhoods vulnerable and disposed to transformation (Opas 2006; 2008; 2014; see Bonilla 2009; Conklin \& Morgan 1996; Grotti 2009; Lima 1999; Londoño-Sulkin 2012; Overing \& Passes 2000; Vilaça 2002; 2005; 2016; Vivieros de Castro 1998; Walker 2013). People living in the same community formed a 'community of substance' (Seeger et al. 1987), which, however, included other smaller communities of substance, such as the evangelical congregation. Each member's physical condition therefore mattered because it had the potential to affect the whole group. This also led people to pay attention to the condition of others' faith 
and their Christian praxis to which it testified. It was not that a person's own scrutinising of their faith and introspection did not matter. As will be discussed below, people were alert to changes in their bodily experiences of faith. In particular, situations in which the physical sensation of God's presence within one's body and of the size of one's ruwekinri did not comply with the person's own estimation of their faith were likely to cause distress (Opas, forthcoming). However, other people also influenced these individual views. As noted above, dreams were of great importance in this respect. I will now examine the role of dreams in the Yine evangelical processes of faith.

\section{Dreams and dream interpretation among the Yine}

As is the case in many Amazonian societies, dreaming and dream interpretation is also an integral part of the Yine people's daily social life. Dreams (gipnawlu) do not constitute a realm separate from the everyday, even if they may be perceived as such. Rather, they are both affected by the prevailing sociocultural and political conditions, and are themselves of great social relevance 'in that they affect how people live in the world and how they relate to others' (Mittermaier 2010). Concerning the Ecuadorian and Peruvian Zápara, it has been argued that dream mastery is linked to political power: dreaming is central to identity practices and is also significant in questions of territoriality and sociality (Bilhaut 2011). Similarly, in a study of the Brazilian Xavante people's dream performances, Laura Graham (1995) shows that dreaming as a social practice is formative of cultural identity and collective memory, and so enables the control of historical processes and change. Among the Yine I have come to know, dreams do not have a political influence extending far beyond the community's social sphere, but sharing and talking about dreams and interpreting them are still highly social events. It would not, however, be correct to say that Yine dreams and dreaming have no wider political significance. Yine psychoactive dreams or dream-like visions especially have been found constructive and directive of regional social relationships in many ways, not least in relation to shamanistic curing practices and processes of modernisation (e.g. Gow 2006). Nevertheless, in the Yine communities with which I am most acquainted, dreams' greatest importance lies in their role as organisers of daily social life within the community or social group. The view I wish to consider here is that of the sociality of dreams as productive of the Yine physical experiences of connection with God or the Holy Spirit. Although dreams or dream-like states induced by use of psychoactive plants are also integral 
to Yine social life, I will here concentrate on 'ordinary' unassisted dreams happening during people's sleep.

Among the Yine people I have heard and been told about many dreams, gipnawlu. Just as in other parts of Amazonia the contents of the dreams my Yine hosts describe vary greatly from very mundane events of daily life such as hunting, agriculture, and domestic tasks, to events considered extraordinary in one way or another. The dreams influence the events of daily life and are anchored to them most commonly through indexicality or analogy. The loud sound of a tambour, reminiscent of the sound of an approaching herd of peccaries, signifies good luck in hunting, and dreaming about forest tortoises warns the dreamer of a forthcoming illness - a tortoise may go without eating for long periods when captured, corresponding to a sick person's loss of appetite. Although the central elements in Yine dreams - for any of these reasons outlined above - are often thought to stand for something else - a game animal or a predator may stand for a human being or foreigner and vice versa, for instance - the metaphorism of the dreams does not mean that they are mere representations for the Yine. The events taking place in dreams and the beings encountered in them are not considered simply as products of human imagination. In relation to the Ecuadorian Runa people Eduardo Kohn discusses human dreams as metaphoric sites of encounter. 'Metaphoric dreams,' Kohn (2013, 141; see also Kohn 2010) writes, 'are ways of experiencing certain kinds of ecological connections among kinds of beings in such a manner that their differences are recognized and maintained without losing the possibility for communication.' Human metaphoric dreams thus 'align the situated points of view of beings that inhabit different worlds' (Ibid.). In other words, Runa dreams allow human beings to interact with beings with different corporeal perspectives without the danger of losing their own perspective. Dreams are thus a privileged realm for interspecies communication. To some extent this applies to Yine dreams as well. When they dream, the Yine may perceive things and beings from a perspective unavailable to them when they are awake. The Yine say that when a person dreams, the dream soul - samenru - leaves the body to wander about. ${ }^{3}$ Encounters with other beings in dreams, be they human, animals, or spirits, are thus understood to take place concretely - the dream souls of different beings interact with each other. One evangelical

3 During my latest fieldwork period among the Yine in 2015 I noted a change happening concerning this aspect of dreams. Some now said that the dream soul (samenru) did not necessarily leave the body when a person was sleeping. I have yet to study the reasons behind this. 
Yine woman told me how she had been visited in a dream by her toddler grandson, who lived far away. He had hugged her, and she had given him a bath. When she awoke, her whole body ached, and she knew from this that the boy had died. The transformed bodily perspective of the now deceased boy, which differed from the living human person's bodily condition, had physically influenced the woman's body. As seen here, such dream interactions are not tied to the normal everyday temporal order and chronology but may involve both past events and those that have yet to take place (cf. Kracke 2010). Dreams may tell of success in a hunting trip to come or of a recent death of a relative living at a distance, for example.

Given the centrality of dreams in Yine social life, it is unsurprising that dreams and dream interpretation are also an important part of Yine Christian lives. However, this importance does not derive solely from custom but is also inherent in Yine Christianity. One evangelical Yine pastor crystallised this when he noted, in an allusion to Numbers 12:6, at a meeting following a congregant's testimony concerning a dream, that 'God says: through dreams I shall reveal Myself'. ${ }^{4}$ Several Yine evangelicals told me of dreams that had involved elements that were considered Christian: angels, lambs, and doves, for example. Nevertheless, they also interpreted dreams with no specific Christian imagery from within a Christian framework. While positive dreams were often interpreted as signs of God's grace or as answers to prayer, negative or threatening dreams were considered either Satan's attempts to test the person - as noted by the woman in this article's opening citation - or God's warnings of approaching threats. Examples of such dreams were, for example, the above-mentioned dream that a tambour playing was a promise of good luck in hunting, while a snakebite in a dream was understood as a warning which led to the dreamer not going on the hunting trip planned for the following day. Thus, dreams, with or without specific Christian imagery, were proof of God's existence for the Yine Evangelicals: they made God alive and tangible. Although metaphors were part of Yine dream explanations, this tangibility was not only a metaphor. As noted above, different beings and entities, be they visible or invisible, animate or inanimate, could influence one another corporeally in the Yine social world, and encounters taking place in dreams could have physical consequences. Similarly, God, the Holy Spirit, and Satan were also considered capable of

4 Numbers 12:6 reads: 'He said, "Listen to my words: 'When there is a prophet among you, I, the Lord, reveal myself to them in visions, I speak to them in dreams."'' (The Holy Bible, New International Version). 
physically influencing people (and especially their faith organ, ruwekinri), and through consubstantialisation the whole community of believers, in and through dreams. This was why dreams were never merely a concern for the individual.

\section{Co-acting experiences of the divine: the sociality of Christian dreaming}

As noted, Yine dreaming as a way to experience the presence of God was not something that only involved the individual and God (or other divinities), but extended into the social space constituted by human-to-human relationships. It was in telling one's dreams to fellow Christians, either as testimonies at church or more informally among family members, that the others became most concretely part of these processes of creation of the Christian lifeworlds and physicalities.

The idea that dreams occupy an important place in the joint production and re-production of lifeworlds is not new. For example, in her examination of Amazonian dreams as a form of communication Laura Graham (1995, 116) notes that among the Brazilian Xavante songs are an important means of externalising dreams: the re-presentation of dreams offers a means of 'signalling the uniqueness of individual subjectivity and the sociability among individuals'. Although Yine dream-telling practices, being enacted at quite casual events, were not as ritualised as they were among the Xavante, their dream-telling can still be said to exist as an institution aimed at forming and re-producing the conditions for sociable life, not merely in the abstract but also physically. 'You have to tell others about your dreams,' one evangelical Yine woman in her fifties cited at the outset of this article explained to me, 'otherwise the bad things in the dreams will come to pass.' When I was travelling with her for about a week in Central Peruvian Amazonia, every morning she told me the dreams she had had during the night. At least once during the week, motivated by her nightly dream, she phoned her spouse to verify that everything was all right with him. In sharing their dreams with each other, the Yine attempted to ensure that the influence of the social others encountered in dreams would not leak uncontrollably into the sphere of normal daily existence, and so possibly have unwanted effects. The situation was akin to the Yine avoidance of entering the forest alone: they always went with a companion because it was thought that alone the risk of being influenced by the consubstantialising practices of other nonhuman beings was too great (Opas 2014; Vilaça 2005). Telling others about one's dreams was a way to control and protect one's own human bodily 
condition and that of those around one. Nevertheless, these others were not merely passive bystanders but were also actively involved in these processes. This was apparent in Yine evangelicals' dreaming and their experiences of God's influence in their lives and bodies.

There were various ways and situations in which social others - fellow Christian believers - could participate in the formation of the individual dreamer's experiences of God's presence to co-act the experiences, and in which people's inner experiences could influence the collectivity as well as the dreaming subjects themselves. The most formal such situations were people's testimonies at the evangelical church. Once, an elderly Yine woman gave a testimony of God's presence in her life at the evangelical church in one of the communities in the Madre de Dios region, describing how Satan had tempted her in her dream. She had been crossing the village river by walking on the water when a massive wave approached her. The wave almost drowned her, but by thinking of God, she could swim to the shore. In her opinion this dream was about Satan testing her faith. Had the wave swept her away and she had drowned, it would have proved that her faith was not strong enough. For her, this dream was proof of her faith: the actions of her dream soul, ungoverned by her daily consciousness, corresponded well to her own experience of her Christian condition. However, at the church this interpretation was subject to the evaluation of others. I witnessed no case in which the dreamer's testimony was seriously questioned, but this was a possibility, as the congregation often engaged in reflection about the significance of the testimonies presented and their place in relation to the dualist battle between good and evil. In this case, however, there was no doubt concerning the woman's testimony. Being very old, she was rarely able to walk to the church to participate in the meetings, but having gained strength in and through the dream she was able to come to share it. This strength was enough to verify her experience. The dream was considered to have added to her physical strength and presumably, although this was not actually said, to the size of her ruwekinri. The congregation's approval, their legitimising of the woman's interpretation, both further reinforced her Christian condition but also positively influenced other's Christian bodies through its consubstantialising effect: the dream worked to repel Satan's forces.

Approval or disapproval following dreaming and dream-sharing were not the only means for others to influence people's experiences of the divine. Fellow Christians also co-acted to empower each other to resist Satan's temptations in dreams. One evangelical Yine man in the Urubamba 
region in Peru told me of the dream experiences he had had when he was trying to be cured of cancer. During the treatments, when the man was at his weakest, his relatives had instructed him not to accept any food offered to him by deceased relatives in his dreams. 'Do not receive food from your relatives - they are already with Satan,' they had said. The sharing of food was one of the primary means by which the Yine created communities of similars, and was also important for the same reason in different humannonhuman/spirit relationships (Opas 2006). Thus, to strengthen not only the man's body, but his consubstantiality with his living relatives, they tried to keep the man well-fed, and they also instructed him to decline any gifts of food from the deceased. Consequently, the man explained, when he was offered food in his dream he was strong enough to resist the temptation to be reunited with his deceased kin who were destined to be separated from heaven, and to decline the offer. ${ }^{5}$ This was taken to prove his faith in God and was considered the decisive moment when his recovery began. By keeping the man well-fed and by warning him of possible dangers, the man's relatives could influence the outcome of the encounters the man had in his dreams, and thus co-act in the generation of his and their own experiences of God's work in their lives.

Food also occupied a central place in another case of evangelical dreaming I encountered. An evangelical man in the Madre de Dios region told me that he had had a dream in which an unknown person he had understood to be an angel had given him two loaves, which he had eaten. He compared the bread to the (fish and) bread distributed by Jesus, and saw his acceptance of this gift both as proof that his ruwekinri was willing to receive such a blessing and as an episode that would contribute to the growth or strengthening of his faith, i.e. the growth of his ruwekinri: 'I think my soul will now increase in size,' he told me. However, things took a different turn. After the dream he had no more dreams with a specifically Christian content. This was a difficult situation, because as one of the evangelical brothers long involved in organising evangelical church activities in his community he was expected to be a model for others. Although they were supportive for a while, the congregation's comments slowly started to reflect bewilderment and questioning. Was there a problem with his faith? The man himself began to think that the food may not have been offered to him by an angel after all, but was rather part of Satan's plan. Eventually, his doubt led to him losing the physical sensation of his ruwekinri, which he had sensed as a feeling of

5 On deceased kin attempting to get the living to join them, see Gow 1991; Taylor 1996. 
pressure or fullness in his chest, and - although there were other reasons contributing to the decision - to his withdrawal from his active role at the church (see Opas, forthcoming). It is not clear whether his failure to dream as a Christian resulted from the congregation's or his own doubting of his faith. In any case, although he did not wish to blame his fellow-Christians, at least not in my presence, it was clear that the pressure the congregation put on him - even though to my knowledge the issue was never publicly addressed at the church - added to his doubt and influenced his physical experience of being connected with God.

These three cases related to dreams - approved testimonies at church, collective uniting against the forces of Satan, and the failed process of the collective generation of faith - demonstrate that the Yine dreams or dreaming can, indeed, be viewed as a nexus of social relationships that works to produce and legitimate, and inhibit or perhaps even prevent, the experiences people have of God's presence in their lives and within their bodies. Being a Christian and having a Christian body are not merely the individual person's subjective experiences but come to be as co-acted, jointly produced. It has already been noted that especially in many charismatic or Faith Christian environments the Word is in various ways made flesh in the believers' bodies, and that the body can therefore be held as an index of the believer's spiritual state (Coleman 2006, 170-172). These situations also involve fellow believers' moral evaluations, which affect the individual's experience of their faith and may cause social discrepancies within the congregation or a group of believers. The Yine evangelicals' case accords with this view to a great extent. There is, however, one important amendment that the Yine case brings to the discussion. As in the Yine social cosmos people affect each other's bodies through consubstantialising practices such as the sharing of food, physical closeness, and living in proximity, the collective evaluations of a person's faith are concretely and physically tied to the spiritual success of the congregation and its members. The Christian condition of every member's body also affects - although to a varying degree - the bodies of others and, importantly for this article, others' experiences of God's presence within one's body, especially in and as the faith organ, ruwekinri.

Although at first sight such processes of consubstantialisation through dreams may appear specific to Amazonian Christianities, dreaming has also been found to have a direct effect on people's lived worlds in other Christian contexts (Bulkeley et al. 2009; Eves 2011; Lohmann 2000). Dreaming is also in many ways parallel to such phenomena as having visions and being 
possessed. Given the specificity of the different cases it becomes important, however, that we find a language through which these parallel phenomena can be linked to, and compared with, one another. I find the notion of mimesis useful for this purpose. I draw here on Michael Taussig's and Jon Mitchell's discussions of the topic. For Taussig $(1993,78)$, who played an important role in developing the notion of mimesis in anthropological and ethnographical analysis, mimesis is 'a space between sameness and otherness, of identity and alterity'. Building on this, Jon Mitchell (2015) has analysed Maltese Catholic statues and visions as mimetic points of encounter between the mundane and the transcendent. In his analysis statues and visions transcend simple definitions of representation because they draw together signifier and signified in a mimetic presence. Although they imitate and thus represent, they also defy representation and create something new - they create relationships. Rather than mere repetition, mimesis is thus a form of 'creative appropriation'. Building on Mitchell's analysis, I suggest that the Yine dream encounters and co-acted experiences of the divine can be productively analysed as instances of what I will call 'affective mimesis'. By affective mimesis I do not refer to the unconscious imitation forming the basis of human identity or ego found in the works of thinkers such as Freud and Nietzsche, and used in literary and film studies, for example (e.g. Lawtoo 2010; 2013). Rather, I wish to depart from the term's psychological uses and deploy it to emphasise the materiality and sociality of dreaming and faith. Underlining the capacity of bodies to affect and be affected (Blackman 2012; see Bialecki 2015) and of dreams to draw signifier and signified together in a mimetic presence working to generate something new instead of simply imitating and re-presenting, I use the notion of 'affective mimesis' to refer to the process in which experiences of being connected with the divine and of the generation of faith take place through physical, i.e. very material, coaction in dreams and in negotiations about their significance, for example. In the cases discussed above the dreamers' bodies are affected by those of deceased and living relatives, angels, and devils through material practices (physical touch, the sharing of - or the refusal to share - food, and giving testimonies), thereby creating experiences of God's (or Satan's) presence in one's life and body.

\section{Revisiting the human-God relationship}

Above I have noted that previous studies of people's experiences of God's presence in their bodies have largely concentrated on individuals' experi- 
ences and on the individual human subject's relationship with God. I have also argued that in our studies we should pay more attention to the role of social others in these relationships. To conclude my discussion I wish, perhaps at first sight somewhat contradictorily, to return to the relationship between the human being and God. There is, however, a good reason to do this, which is related to the way in which God as the other in these relationships has often been contemplated in research.

In studies of human-God relationships the latter is often considered to be somewhat inactive. Although God is interactive and tangibly present in believers' own accounts, scholarship has taken a somewhat biased approach, concentrating on the individual believer's side of the relationship. This tendency owes much to scholarship's difficult relationship with the Christian divine (Robbins 2003; Bialecki 2014; Espirito Santo \& Tassi 2013, 21). The recognition of God's agency in research has often been taken to equate with an acceptance of God's ontological existence, which has inhibited attempts to take God seriously in research. Nevertheless, as God is an active agent in people's accounts, and as the actions of God, angels, and Jesus are considered to have physical and tangible influences on people's bodies and worlds, we cannot continue to dismiss their agency. Recent post-humanist and materialist turns and, in relation to Amazonia the ethnography of human-nonhuman relations and objecthood, have paved the way for research that is neither restricted to nor begins with the human being (e.g. Espirito Santo \& Tassi 2013; Henare \& al. 2007; Mitchell 2015; Santos-Granero 2009a; Tsing 2013; Viveiros de Castro 1998). It is becoming clear that when we speak about social relationships we cannot discard other-than-human beings or objects and things. In the Amazonian context social networks have been shown to include very different kinds of agent. Plant spirits - through plants' materiality - heal and guide people (Caiuby Labate \& Cavnar 2014), and hammocks (Walker 2013) and flutes (Santos-Granero 2009b), for example, are co-constitutive of human bodies. Within this framework it would seem odd if the Christian God, the Holy Spirit, and Satan were denied an active agency. I therefore wish to revisit the human-God relationship concerning human experiences of the divine presence from this perspective. Indeed, in relation to the Yine social cosmos, God assumes the agentive position quite easily. In the Yine dream world people's dream souls are considered to interact with a host of different beings, including plant spirits, witches, shamanic helper spirits, and 
Christian divinities. ${ }^{6}$ Although it is usually angels, and only rarely God in person, who are seen and interacted with in these dreams, this does not nullify God's agency.

Regarding two-way communication between Yine evangelicals and God, dreaming was intertwined with praying. In their prayers Yine people could ask for healing from illness, health for themselves or their loved ones, blessing for a relative living far away or travelling, the strengthening of faith, and signs of God's presence in their lives. People expected or hoped that God would answer such requests by causing the person to encounter in dreams angels, Jesus Christ, a bright light, lambs, or other things commonly interpreted as somehow Christian. Having such dreams was understood to have a direct and tangible influence on a person's daily life. Whether interpreted as confirmation of a person's faith or as a promise of healing from an illness, these dreams were considered to lead to the strengthening of the person's ruwekinri and to help them live as good Christians.

Such reciprocal processes are exemplified by the many cases in which Yine evangelicals have dreams related to healing. One woman in her fifties, for example, told me how she had suffered from serious pain in one of her legs for several years. The illness was commonly understood among the Yine as being caused by witchcraft. The woman was already on the verge of committing suicide because she could no longer tolerate the pain. Nevertheless, as a devout Christian, she prayed once more. In the dream that followed she saw a white-robed man, whom she identified as an angel, who told her to stand up and walk. In the morning, when she woke up, she stood up and her leg no longer hurt, at least not as badly as before. She was convinced that this was an answer to her prayer.

Examined from the perspective of affective mimesis, this dream does not mechanically reproduce the relationships in accordance with a predetermined formula and imagery, but rather works sensuously to constitute the human-divine relationship. The angel encouraging the woman in her dream to stand up and walk presents a case not merely of reproducing an image of white-robed angels as God's messengers and repeating the biblical theme of the cripple healed by Jesus, but may instead be understood as a mimetic encounter, and as such as creating something new. It is God's answer to the woman's specific prayer and a confirmation of her faith. However, it is such not only as an intangible promise but as an affect: just as in Genesis Jacob's fight with God is described as a tactile experience that left him limp-

6 In accounts dating back to the early 20th century great shamans, during their intoxication, could travel to heaven and see God (Gow 2006). 
ing (Gen 31: 22-31; see also Knauss 2013, 110), the encounter with the angel affected the woman's body by removing her pain and reinforcing her faith through the strengthening of her faith organ, ruwekinri. As discussed above, the Christian actor, in this dream the angel, was neither conceptualised nor experienced as a product of the imagination: in the dream an encounter between the woman's dream soul and the angel was said to have taken place. In general, then, we can see here that God, as an active agent (even when acting via messengers), holds a central place in the co-active production of faith sensations, and that the encounters taking place in dreams work to form and modify, and by their failure to appear, even end, people's relationships with God. By so doing, just as the Catholic statues Mitchell discusses, they affect the person's daily life and create lifeworlds. The encounter between the angel and the woman had the effect of changing her life. Having been on the verge of suicide, she now had enthusiasm for life. The case therefore affords a good demonstration of the importance of taking God and other Christian divinities seriously in analysing Christian lived religiosity.

\section{Conclusion}

In this article I have examined the inter-linkages of faith, knowledge, and materiality among the Yine people of Peruvian Amazonia. I have asked how the Yine 'know' the extent to which and how they are connected with God, the extent of their faith, and how social others are part of these processes. By examining Yine evangelical dreaming and dream-sharing practices, I have attempted to show that their experiences of God's presence in their lives, and most focally in their bodies, are the result of both human-to-human and human-to-divine co-action.

Yine dreams are in this light shown to be a nexus, a battleground for good and evil, and an arena for the negotiation of personal faith and social relationships both with the divine and with fellow human beings. Among the Yine dreams are at the same time highly individual and thoroughly social, but both in a very concrete physical sense. The Yine evangelicals - through their shared physicality and the property of their bodies in influencing one another in physical interaction - inhabit the same socio-moral space inhabited by God, which either nourishes their faith - understood as localised in the heart - or forming a special faith-organ, ruwekinri, or inhibits it from growing. It is not therefore of no consequence if someone fails to have Christian dreams, and for this reason the sharing of dreams occupies an important place in Yine evangelicals' private and congregational lives. Although the 
processes of interpretation involve many disagreements, the importance of dreams as channels for communicating with God and as means to prove one's faith are not contested. The Yine continue to dream their faith into being.

$$
* * *
$$

MINNA OPAS is Senior Research Fellow in Comparative Religion at the Turku Institute for Advanced Studies, University of Turku. Email: minna.opas@utu.fi

\section{Bibliography}

\section{Austin-Broos, Diane}

1997 Jamaica Genesis: Religion and the Politics of Moral Orders. Chicago: University of Chicago Press.

\section{Bialecki, Jon}

2014 Does God Exist in Methodological Atheism? On Tanya Lurhmann's 'When God Talks Back' and Bruno Latour. - Anthropology of Consciousness 25(1), 32-52.

2015 Affect: Intensities and Energies in the Charismatic Language, Embodiment, and Genre of a North American Movement. - Simon Coleman \& Rosalind Hackett (eds), The Anthropology of Global Pentecostalism and Evangelicalism, 95-108. New York: New York University Press.

\section{Bialecki, Jon \& Girish Daswani}

2015 What is an Individual? The View from Christianity. - HAU Journal of Ethnography Theory 5(1), 271-94.

\section{Bilhaut, Anne-Gaël}

2011 El sueño de los záparas: patrimonio onírico de un pueblo de la Alta Amazonía. Quito: FLACSO.

\section{Blackman, Lisa}

2012 Immaterial Bodies: Affect, Embodiment, Mediation. London: Sage.

\section{Bonilla, Oiara}

2009 The Skin of History: Paumari Perspectives on Conversion and Transformation. - Aparecida Vilaça \& Robin Wright (eds), Native Christians. Modes and Effects of Christianity among Indigenous Peoples of the Americas, 127-46. Farnham: Ashgate.

\section{Brahinsky, Josh}

2012 Pentecostal Body Logics: Cultivating a Modern Sensorium. - Cultural Anthropology 27(2), 215-38. 
Bulkeley, Kelly \& Kate Adams \& Patricia M. Davis (eds)

2009 Dreaming in Christianity and Islam: Culture, Conflict, and Creativity. New Brunswick \& London: Rutgers University Press.

\section{Caiuby Labate, Beatriz \& Clancy Cavnar (eds)}

2014 Ayahuasca Shamanism in the Amazon and Beyond. Oxford \& New York: Oxford University Press.

Cattoi, Thomas \& June McDaniel

2011 Perceiving the Divine through the Human Body. London \& New York: Palgrave Macmillan.

\section{Chidester, David}

2005 The American Touch. Tactile Imagery in American Religion and Politics. - Constance Classen (ed.), The Book of Touch, 49-65. Oxford: Berg Publishers.

\section{Coleman, Simon}

2006 Materializing the Self: Words and Gifts in the Construction of Charismatic Protestant Identity. - Fenella Cannell (ed.), The Anthropology of Christianity, 163-84. Durham \& London: Duke University Press.

\section{Conklin, Beth \& Lynn Morgan}

1996 Babies, Bodies and the Production of Personhood in North America and a Native Amazonian Society. - Ethos 24(4), 657-94.

\section{Csordas, Thomas J.}

1994 The Sacred Self: A Cultural Phenomenology of Charismatic Healing. Berkeley: University of California Press.

\section{Daswani, Girish}

2011 (In-)Dividual Pentecostals in Ghana. - Journal of Religion in Africa 41 (3), 256-79.

\section{de Witte, Marleen}

2009 Modes of Binding, Moments of Bonding. Mediating Divine Touch in Ghanaian Pentecostalism and Traditionalism. - Meyer, Birgit (ed.), Aesthetic Formations. Media, Religion and the Senses, 183-205. New York: Palgrave MacMillan.

\section{Engelke, Matthew}

2007 A Problem of Presence: Beyond Scripture in an African Church. University of California Press.

\section{Espirito Santo, Diana \& Nico Tassi (eds)}

2013 Making Spirits: Materiality and Transcendence in Contemporary Religions. London \& New York: I. B. Tauris.

\section{Eves, Richard}

2011 Pentecostal Dreaming and Technologies of Governmentality in a Melanesian Society. - American Ethnologist 38(4), 758-73. 


\section{Gavrilyuk, Paul L. \& Sarah Coakley}

2011 The Spiritual Senses: Perceiving God in Western Christianity. New York: Cambridge UP.

\section{Gow, Peter}

1991 Of Mixed Blood. Oxford: Oxford University Press.

2006 Forgetting Conversion. The Summer Institute of Linguistics Mission in the Piro Lived World. - Fenella Cannell (ed.), The Anthropology of Christianity, 211-39. Durham \& London: Duke University Press.

\section{Graham, Laura R.}

1995 Performing Dreams: Discourses of Immortality among the Xavante of Central Brazil. Austin: University of Texas Press.

\section{Griffth, R. Marie}

2004 Born again Bodies. Flesh and Spirit in American Christianity. Berkeley: University of California Press.

Grotti, Vanessa E.

2009 Protestant Evangelism and the Transformability of Amerindian Bodies in Northeastern Amazonia. - Aparecida Vilaça \& Robin Wright (eds), Native Christians. Modes and Effects of Christianity among Indigenous Peoples of the Americas, 109-26. Farnham: Ashgate.

\section{Hart, Kevin \& Barbara Wall}

2005 Experience of God: A Postmodern Response. New York: Fordham University Press.

\section{Harding, Susan}

2000 The Book of Jerry Falwell: Fundamentalist Language and Politics. Princeton, NJ: Princeton University Press.

\section{Henare, Amiria, Martin Holbraad \& Sari Wastell (eds)}

2007 Thinking through Things: Theorising Artefacts Ethnographically. London: Routledge.

\section{Keane, Webb}

2007 Christian Moderns: Freedom and Fetish in the Mission Encounter. Berkeley: University of California Press.

\section{Klaver, Miranda \& Linda van de Kamp (eds)}

2011 Embodied Temporalities in Global Pentecostal Conversion. Special issue of Ethnos 2011(4).

Knauss, Stephanie

2013 Aisthesis: Theology and the Senses. - CrossCurrents 63(1), 106-21.

Kracke, Waud

2010 Dream Interpretation in the Amazon. - Journal of Developmental and Behavioral Pediatrics 31(4), 367-8. 


\section{Lawtoo, Nidesh}

2010 The Horror of Mimesis: "Enthusiastic Outbreak[s]" in Heart of Darkness. - Conradiana 42(1/2), 45-74.

2013 The Phantom of the Ego: Modernism and the Mimetic Unconscious. UNIL. East Lansing, MI: Michigan State University Press.

Lima, Tanya

1999 The Two and Its Many: Reflection on Perspectivism in a Tupi Cosmology. - Ethnos 64(1), 107-31.

\section{Lohmann, Roger Ivar}

2000 The Role of Dreams in Religious Enculturation among the Asabano of Papua New Guinea. - Ethos 28(1), 75-102.

\section{Londoño Sulkin, Carlos D.}

2012 People of Substance: An Ethnography of Morality in the Colombian Amazon. Toronto: University of Toronto Press.

\section{Luhrmann, Tanya}

2004 Metakinesis: How God becomes intimate in contemporary U.S. Christianity. - American Anthropologist 106(3), 518-28.

2012 When God Talks Back. Understanding the American Evangelical Relationship with God. New York: Vintage Books.

\section{McGuire, Meredith}

2003 Why Bodies Matter: A Sociological Reflection on Spirituality and Materiality. - Spiritus: A Journal of Christian Spirituality 3(1), 1-18.

\section{Meyer, Birgit}

2008 Religious Sensations: Why Media, Aesthetics, and Power Matter in the Study of Contemporary Religion. - Hent de Vries (ed.), Religion: Beyond a Concept, 704-23. New York: Fordham University Press.

2010 Aesthetics of Persuasion. Global Christianity and Pentecostalism's Sensational Forms. - South Atlantic Quarterly 109(4), 741-63.

\section{Mitchell, Jon P.}

2015 Ontology, Mimesis, and Divine Intervention: Understanding Catholic Visionaries. - Michael Bull \& Jon Mitchell (eds), Ritual, Performance and the Senses, 11-30. London: Bloomsbury Publishing.

\section{Mittermaier, Amitra}

2010 Dreams That Matter: Egyptian Landscapes of the Imagination. Berkeley: University of California Press.

\section{Mosko, Mark}

2010 Partible Penitents: Dividual Personhood and Christian Practice in Melanesia and the West. - Journal of the Royal Anthropological Institute 16(2), 215-40. 


\section{Opas, Minna}

2006 Mutually Exclusive Relationships: Corporeality and Differentiation of Persons in Yine (Piro) Social Cosmos. - Tipití: Journal of the Society for the Anthropology of Lowland South America 3(2), 111-30.

2008 Different but the Same: Negotiation of Personhoods and Christianities in Western Amazonia. Unpublished PhD thesis, University of Turku, Finland.

2014 Ambigüedad epistemológica y moral en el cosmos social de los yine. - Anthropologica 31(31), 167-89.

forthcoming Organic Faith in Amazonia: De-indexification, Doubt and Christian Corporeality. - Minna Opas \& Anna Haapalainen (eds), Christianity and the Limits of Materiality. London: Bloomsbury.

Orsi, Robert A.

2006 Between Heaven and Earth: The Religious Worlds People Make and the Scholars Who Study Them. Princeton: Princeton University Press.

\section{Overing, Joanna \& Alan Passes}

2000 Anthropology of Love and Anger: The Aesthetics of Conviviality in Native Amazonia. London: Routledge.

\section{Robbins, Joel}

2002 My Wife Can't Break off Part of Her Belief and Give It to Me: Apocalyptic Interrogations of Christian Individualism among the Urapmin of Papua New Guinea. - Paideuma 48, 189-206.

2003 What is a Christian? Notes toward an Anthropology of Christianity. - Religion 33(3), 191-9.

\section{Santos-Granero, Fernando (ed.)}

2009a The Occult Life of Things: Native Amazonian Theories of Materiality and Personhood. Tucson: The University of Arizona Press.

\section{Santos-Granero, Fernando}

2009b From Baby Slings to Feather Bibles and from Star Utensils to Jaguar Stones: The Multiple Ways of Being a Thing in the Yanesha Lived World. - Fernando Santos-Granero (ed.), The Occult Life of Things: Native Amazonian Theories of Materiality and Personhood, 105-27. Tucson: The University of Arizona Press.

\section{Seeger, Anthony \& Roberto da Matta \& Eduardo Viveiros de Castro}

1987 [1979] A construção da pessoa nas sociedades indígenas brasileiras. - J. Pacheco de Oliveira Filho (ed.), Sociedades indígenas $\mathcal{E}$ indigenismo no Brasil, 11-29. Rio de Janeiro: UFRJ/Marco Zero.

\section{Taussig, Michael}

1993 Mimesis and Alterity: A Particular History of the Senses. Ney York: Routledge. 


\section{Taylor, Anne-Christine}

1996 The Soul's Body and Its States: An Amazonian Perspective on the Nature of Being Human. -Journal of the Royal Anthropological Institute 2, 201-15.

\section{Tsing, Anna}

2013 More-than-Human Sociality: A Call for Critical Description. - Hastrup, Kirsten (ed.), Anthropology and Nature, 27-42. New York: Routledge.

\section{Vilaça, Aparecida}

2002 Making Kin Out of Others in Amazonia. - Journal of the Royal Anthropological Institute 8, 347-65.

2005 Chronically Unstable Bodies: Reflection on Amazonian Corporalities. - Journal of the Royal Anthropological Institute 11, 445-64.

2011 Dividuality in Amazonia: God, the Devil, and the constitution of personhood in Wari' Christianity. - Journal of the Royal Anthropological Institute 17(2), 243-62.

2016 Praying and Preying: Christianity in Indigenous Amazonia. Berkeley: University of California Press.

\section{Viveiros de Castro, Eduardo}

1998 Cosmological Deixis and Amerindian Perspectivism. - Journal of the Royal Anthropological Institute 4, 469-88.

\section{Walker, Harry}

2013 Under a Watchful Eye: Self, Power and Intimacy in Amazonia. Berkeley: University of California Press. 